\title{
The Effect of Maternal Role Intervention with Increased Maternal Role Identity Attainment in Pregnancy and Infant Growth: A Meta-analysis
}

\author{
Warsiti Warsiti $^{1 *}$, Intansari Nurjannah ${ }^{2}$, Lely Lusmilasari ${ }^{2}$ \\ ${ }^{1}$ Doctoral Program, Faculty of Medicine, Public Health and Nursing, Universitas Gadjah Mada, Yogyakarta, Indonesia; \\ ${ }^{2}$ Department of Nursing, Faculty of Medicine, Public Health and Nursing, Universitas Gadjah Mada, Yogyakarta, Indonesia
}

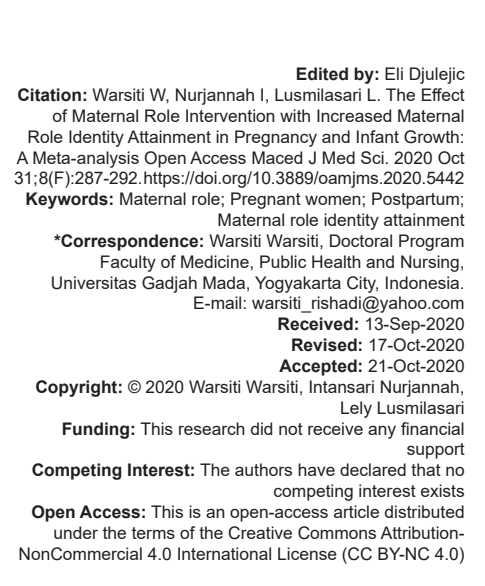

\section{Background}

Almost all maternal mortality happened in developing countries. Unplanned pregnancy is among the most troubling public health problems and major reproductive health. The prevalence of unwanted pregnancy has been reported in previous studies approximately $35-42 \%$ and revealed that $19 \%$ of the pregnancy was improper pregnancy and $16 \%$ was an unwanted pregnancy. Women with unplanned pregnancy were exposed to some problems such as mental and emotional problems increased during pregnancy and postpartum which endanger positive interaction between mother and baby as well as maternal role identity achievement [1], [2].

Mercer in 1985 found that maternal role attainment (MRA) is a process in which mother achieves maternal role qualification as a mother. The process of MRA begins during pregnancy and continues 4-6 months after delivery. MRA consists of 4 steps: (1) Waiting (preparation for the birth of a child during pregnancy), (2) official step (role-playing); familiarity and improved attachment to the baby, learning how to care for the baby, (3) informal step (role achievement); reacting to full possessions of the baby, creating self-induced maternal behaviors and increased self-confidence in taking care of the newborn care, and (4) personal step (maternal role identity); fun correlation between mother-newborn, love of breastfeeding and feeling competent [3].

Maternal role identity might be achieved in 1 month or several months. Factors that have been shown related to the achievement of motherhood are mother, newborn, and the environment. Maternal variables include the age of mother, mother-infant separation, culture, social-economic level, marital status, parental self-confidence, labor experience, premature newborn treatment, stress, social support, personality, understanding the newborn, role conflict, newborn physical appearance, and environmental variables consist of social support by spouse and family member and training by health officers [4].

Various government efforts have been made both through infrastructure development and policies to improve maternal and infant welfare. There are no specific programs intended for young mothers to improve the identity of the maternal role but have not yet been integrated with the general maternal and child 
health service programs. There has been no evaluation that assessed the social aspect. Adolescents who have become mothers are seen as adults, so they do not need special intervention [4].

A previous study stated the program promoting maternal role was effective in maternal role achievement in young mothers with unplanned pregnancy [5]. Maternal identity training based on Mercer's theory is associated with creating a maternal role and understanding the child [6]. Another study revealed that maternal role training program for nulliparous women associated interaction between mother, baby, and infant growth [7]. Previous research found that training had no correlation with maternal identity [8]. MRA training cannot be applied thoroughly in African-American women [9].

Therefore, we aimed to determine the effect of maternal role intervention with increased maternal role identity attainment in pregnancy and infant growth by conducting a meta-analysis study in order to draw stronger conclusions.

\section{Methods}

\section{Study design and research sample}

In this meta-analysis study, we followed the Preferred Reporting Items for Systematic Reviews and Meta-Analysis (PRISMA) Statement [10]. The samples of this research included published research articles which were published from January 2000 to May 2018 in PubMed, ProQuest, and EBSCO of online article databases. The inclusion criteria of this are research on the effect of maternal role intervention with increased maternal role identity attainment in pregnancy and infant growth with randomized controlled trial design, cohort study, and case-control. The exclusion criteria are research which not available in full-text.

\section{Operational definition}

The variables in this study include independent variables; age of mother, labor experience, motherinfant separation, self-confidence, self-concept, flexibility, health status, anxiety, depression, satisfaction, affection, infant behavior, infant health status, infant characteristics, family function, family support, husband and wife's relationship and culture. A dependent variable which was maternal role attainment.

\section{Research procedure}

This study is conducted by gathering data through the identification of published research articles on the effect of maternal role intervention with increased maternal role identity attainment in pregnancy and infant growth (Figure 1).

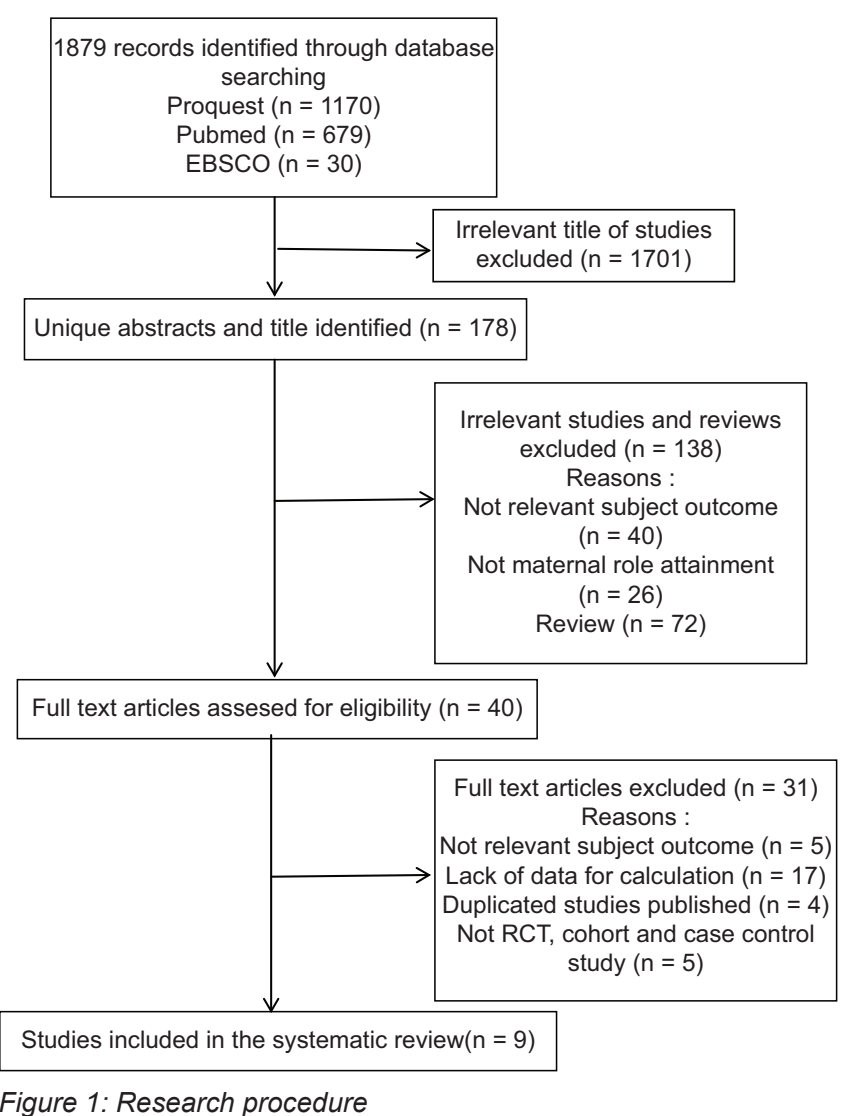

\section{Data collection}

Investigation was done using some keywords as follows: ([maternal] AND role attainment OR role identity) AND (maternal age OR birth experience OR early maternal-infant separation OR self-esteem OR selfconcept OR flexibility OR childrearing attitudes OR health status OR anxiety OR depression OR role strain OR gratification OR attachment OR infant temperament OR infant health status OR infant characteristics OR family OR family functioning OR social support OR mother-father relationship OR culture)).

Search is limited only research articles in English. The study subject was limited to subjects of human. Publication time limited from January 2000 until May 2018. Articles with potentially relevant titles are reviewed abstract, while irrelevant articles are excluded from the study. Furthermore, the article is reviewed abstract. Articles that have potentially relevant abstracts will then be reviewed in full-text, while irrelevant articles are excluded from the study. The design of the study (randomized controlled trial, case-control, or cohort study).

\section{Data analysis}

The analysis held to get the value of weighted mean difference which is the combined mean difference value from the research. The analysis was held to get the value of pooled weighted mean difference which is the combination of weighted mean difference value from each research. A random effect model was used when 
significant heterogeneity was observed; otherwise, a fixed effect model was performed. Data are analyzed using Review Manager 5.3 (RevMan 5.3).

\section{Result}

Identification on 1879 articles, done through selection and review on the title of the articles, then reviewed abstract, reviewed in full-text. Meanwhile, irrelevant articles are excluded from the study. Study selection conducted nine studies related to the effect of maternal role intervention with increased maternal role identity attainment in pregnancy and infant growth (Table 1).

Based on the results of the systematic review, there are nine studies (six studies with clinical trial and three studies with cohort study). The research variables analyzed based on the systematic review that has been done are infant health status, maternal competency, depression, self-confidence, and MRA for maternal satisfaction.

Forest plot of infant health status, maternal competency, depression, self-confidence, and maternal role attainment for maternal satisfaction with maternal role identity attainment (Figure 2).

Table 1: Systematic review of the effect of maternal role intervention with increased maternal role identity attainment in pregnancy and infant growth

\begin{tabular}{|c|c|c|c|c|c|c|}
\hline Author, year & $\begin{array}{l}\text { Number of } \\
\text { sample }\end{array}$ & Subject & Subject Characteristics & Design & Objective & Result (meaningful variables) \\
\hline $\begin{array}{l}\text { Cooke } \\
\text { et al. [11] }\end{array}$ & 449 & $\begin{array}{l}\text { All women who were } \\
\text { registered to deliver at } \\
\text { three Sydney public } \\
\text { hospitals within one } \\
\text { area health service, } \\
\text { during a 1-month period }\end{array}$ & $\begin{array}{l}\text { Subject was aged between } 16 \\
\text { and } 45 \text { years. Almost all women } \\
\text { married and employed during } \\
\text { the pregnancy }\end{array}$ & Cohort study & $\begin{array}{l}\text { To investigate the relationships } \\
\text { between maternal distress, } \\
\text { breastfeeding cessation, } \\
\text { breastfeeding problems, and } \\
\text { breastfeeding maternal role } \\
\text { attainment }\end{array}$ & $\begin{array}{l}\text { MRA implementation increased } \\
\text { the duration of breastfeeding }\end{array}$ \\
\hline $\begin{array}{l}\text { Barlow } \\
\text { et al.. [12] }\end{array}$ & 53 & $\begin{array}{l}\text { American Indian } \\
\text { adolescents }\end{array}$ & $\begin{array}{l}\text { Subject aged } 12-19 \text { years at } \\
\text { conception and at } 28 \text { weeks' or } \\
\text { earlier gestation }\end{array}$ & $\mathrm{RCT}$ & $\begin{array}{l}\text { To investigate the effect of } \\
\text { paraprofessional-delivered home- } \\
\text { visiting training to promote child care } \\
\text { knowledge, skills, and involvement } \\
\text { among pregnant American Indian } \\
\text { adolescents }\end{array}$ & $\begin{array}{l}\text { A paraprofessional-delivered, } \\
\text { family-strengthening home- } \\
\text { visiting program significantly } \\
\text { increased mothers' child care } \\
\text { knowledge and involvement }\end{array}$ \\
\hline $\begin{array}{l}\text { Ngai et al. } \\
{[13]}\end{array}$ & 184 & $\begin{array}{l}\text { Women in two regional } \\
\text { public hospitals in Hong } \\
\text { Kong that provides } \\
\text { routine childbirth } \\
\text { education programs } \\
\text { with similar content and } \\
\text { structure }\end{array}$ & $\begin{array}{l}\text { Women with primiparous, } \\
\text { singleton, and uneventful } \\
\text { pregnancy, at gestation between } \\
12 \text { and } 35 \text { weeks, and did } \\
\text { not have a past or familial } \\
\text { psychiatric illness }\end{array}$ & $\begin{array}{l}\text { Quasi- } \\
\text { experimental }\end{array}$ & $\begin{array}{l}\text { To determine the impact of a } \\
\text { childbirth psychoeducation program } \\
\text { based on the concept of learned } \\
\text { resourcefulness on maternal } \\
\text { role competence and depressive } \\
\text { symptoms in Chinese childbearing } \\
\text { women }\end{array}$ & $\begin{array}{l}\text { The childbirth psychoeducation } \\
\text { program appears to be a } \\
\text { very promising intervention } \\
\text { for promoting learned } \\
\text { resourcefulness and minimizing } \\
\text { the risk of perinatal depression } \\
\text { in } 1^{\text {st }} \text {-time Chinese childbearing } \\
\text { women }\end{array}$ \\
\hline $\begin{array}{l}\text { Hyun-Ju } \\
\text { et al. [14] }\end{array}$ & 54 & $\begin{array}{l}\text { Women in Postpartum } \\
\text { Centre in Sanhujoriwon, } \\
\text { Korea }\end{array}$ & $\begin{array}{l}\text { Mean of age in experimental } \\
\text { and control group was } 33.4 \text { and } \\
33.0 \text { years, level of education } \\
\text { between two groups was } \\
\text { university or more }\end{array}$ & $\begin{array}{l}\text { A non-equivalent } \\
\text { control group } \\
\text { non-synchronized } \\
\text { design }\end{array}$ & $\begin{array}{l}\text { To investigate the effects of } \\
\text { education and practice of the } \\
\text { maternal role and becoming a } \\
\text { mother using the concepts of } \\
\text { self-confidence in caring, maternal } \\
\text { attachment, and maternal identity }\end{array}$ & $\begin{array}{l}\text { The experimental group showed } \\
\text { significant increases in self- } \\
\text { confidence in caring ( } \mathrm{t}=-3.31 \text {, } \\
p=.002) \text { and maternal identity } \\
(\mathrm{t}=-2.16, p=.036) \text { compared to } \\
\text { the control group }\end{array}$ \\
\hline $\begin{array}{l}\text { Ozkan } \\
\text { et al.. [6] }\end{array}$ & 120 & $\begin{array}{l}\text { Primiparous women } \\
\text { visiting clinic in maternal } \\
\text { hospital of Nene Hatun }\end{array}$ & $\begin{array}{l}\text { Almost respondents were } 17-25 \\
\text { years and high school education } \\
\text { level }\end{array}$ & $\begin{array}{l}\text { Pretest-posttest } \\
\text { quasi- } \\
\text { experimental }\end{array}$ & $\begin{array}{l}\text { To assess the effect of maternal } \\
\text { identity development education on } \\
\text { the maternity role attainment and my } \\
\text { baby perception of primigravidas }\end{array}$ & $\begin{array}{l}\text { The training of identification } \\
\text { development given for the } \\
\text { mothers increased score } \\
\text { averages taken from the scales } \\
\text { of Myself as Mother, My Baby } \\
\text { and the Pharis Self-confidence } \\
\text { Scale }\end{array}$ \\
\hline $\begin{array}{l}\text { Srisomboon } \\
\text { et al.. [5] }\end{array}$ & 58 & $\begin{array}{l}\text { Nulliparous women } \\
\text { referring to health } \\
\text { centers in the city of } \\
\text { Mashhad }\end{array}$ & $\begin{array}{l}\text { The mean age in the } \\
\text { intervention and control groups } \\
\text { was } 24.03 \text { and } 24.19 \text { years }\end{array}$ & $\begin{array}{l}\text { Quasi- } \\
\text { experimental }\end{array}$ & $\begin{array}{l}\text { To determine the impact of maternal } \\
\text { role training program on attainment } \\
\text { of role and role satisfaction in } \\
\text { nulliparous women with unplanned } \\
\text { pregnancy }\end{array}$ & $\begin{array}{l}\text { Maternal role training for } \\
\text { nulliparous women with } \\
\text { unplanned pregnancy during } \\
\text { pregnancy and postpartum } \\
\text { period can help them in maternal } \\
\text { role attainment and maternal role } \\
\text { satisfaction }\end{array}$ \\
\hline $\begin{array}{l}\text { Kordi et al.. } \\
{[16]}\end{array}$ & 67 & $\begin{array}{l}\text { Nulliparous women with } \\
\text { unplanned pregnancies }\end{array}$ & $\begin{array}{l}\text { The mean age of subject units } \\
\text { was } 24.10 \pm 4.3\end{array}$ & Clinical trial & $\begin{array}{l}\text { To determine the impact of maternal } \\
\text { role training program on attainment } \\
\text { of role and role satisfaction in } \\
\text { nulliparous women with unplanned } \\
\text { pregnancy }\end{array}$ & $\begin{array}{l}\text { Maternal role training for } \\
\text { nulliparous women with } \\
\text { unplanned pregnancy during } \\
\text { pregnancy and postpartum } \\
\text { period can help them in maternal } \\
\text { role attainment and maternal role } \\
\text { satisfaction }\end{array}$ \\
\hline $\begin{array}{l}\text { Bagherinia } \\
\text { et al.. [17] }\end{array}$ & 305 & $\begin{array}{l}\text { The } 4^{\text {th }} \text { postpartum } \\
\text { month }\end{array}$ & $\begin{array}{l}\text { The mean age of the } \\
\text { participants was } 23.8(4.0) \\
\text { years and half of the women } \\
(55.1 \%) \text { were aged }<25 \text { years }\end{array}$ & $\begin{array}{l}\text { Longitudinal } \\
\text { study }\end{array}$ & $\begin{array}{l}\text { To investigate the correlation } \\
\text { between mothers' competence and } \\
\text { self-confidence in postpartum period }\end{array}$ & $\begin{array}{l}\text { This study found maternal } \\
\text { competency and self-efficacy a } \\
\text { significantly positive correlation }\end{array}$ \\
\hline
\end{tabular}


Figure 2 showed that there was maternal role effect with increased satisfaction of becoming a mother (weight mean difference $=-2,24[95 \%$ confidence interval $(\mathrm{Cl})-4,19,-0,29])$ and decreased mother depression ([weight mean difference $=-1,93$ $[95 \% \mathrm{Cl}-3,09,-0,78]),(p<0.05)$. Depression and satisfaction variables had homogenous research variation. While, maternal role in supporting infant health, mother competency, and trust in taking care of infants is not associated with maternal role identity attainment $(p>0.05)$.

Funnel plot of infant health status, maternal competency, depression, self-confidence, and maternal role attainment for maternal satisfaction with maternal role identity attainment.

Figure 3 shows that depression and satisfaction variables have a variation of homogenous research for maternal role identity attainment. This is because the plot is symmetrical based on the vertical line means that if the analysis is done on the population, time and place, and different conditions, then the results will be consistent. This is different from infant health status, maternal competency, and self-confidence in caring.

Subgroup analysis based on the effect of maternal role intervention with increased maternal

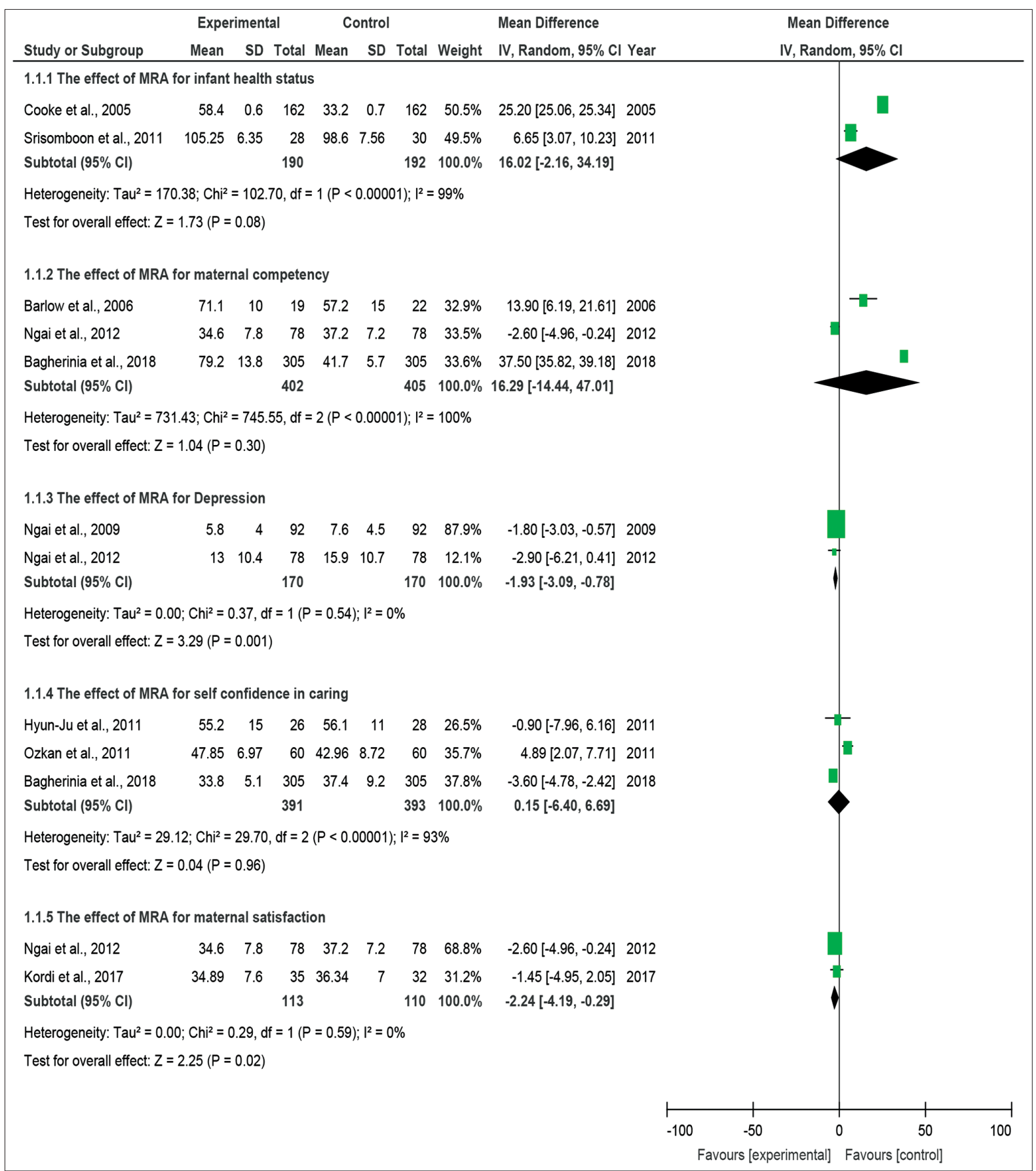

Figure 2: Forest plot of infant health status, maternal competency, depression, self-confidence, and maternal role attainment for maternal satisfaction with maternal role identity attainment 


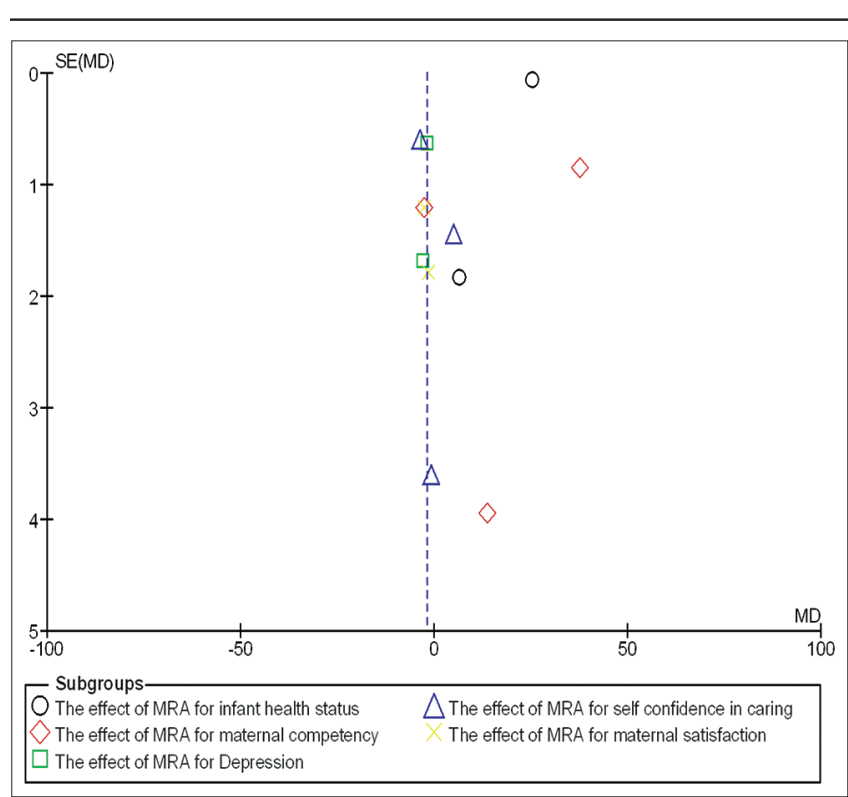

Figure 3: Funnel plot of infant health status, maternal competency, depression, self-confidence, and maternal role attainment for maternal satisfaction with maternal role identity attainment

role identity attainment in pregnancy and infant growth (Table 2).

Table 2: Subgroup analysis based on the effect of maternal role intervention with increased maternal role identity attainment in pregnancy and infant growth

\begin{tabular}{|c|c|c|c|c|c|}
\hline \multirow[t]{2}{*}{ Subgroup } & \multirow{2}{*}{$\begin{array}{l}\text { Number of } \\
\text { studies }\end{array}$} & \multirow{2}{*}{$\begin{array}{l}\text { Pooled risk relative } \\
(95 \% \mathrm{Cl})\end{array}$} & \multirow[t]{2}{*}{$\mathrm{p}$-value } & \multicolumn{2}{|c|}{ Heterogeneity test } \\
\hline & & & & $p$ value & $\mathrm{I}^{2}(\%)$ \\
\hline \multicolumn{6}{|l|}{ Study design } \\
\hline Clinical trial & 6 & $1.59(1.17-2.32)$ & $<0.001$ & $<0.001$ & 49.00 \\
\hline Cohort & 3 & $1.19(0.70-1.98)$ & $<0.001$ & $<0.001$ & 54.56 \\
\hline \multicolumn{6}{|l|}{ Sample size } \\
\hline$<100$ & 4 & $1.15(1.12-2.47)$ & $<0.001$ & $<0.001$ & 58.95 \\
\hline$\geq 100$ & 5 & $1.76(1.61-3.25)$ & $<0.001$ & $<0.001$ & 63.67 \\
\hline
\end{tabular}

Table 2 found that there is a high pooled risk relative of clinical trial study design for identified maternal role identity attainment, pooled risk relative 1.59 (1.17-2.32), heterogeneity test in these studies (Pheterogeneity $\leq 0.001 ; \mathrm{I}^{2}=49 \%$ ). While sample size $<100$ and $\geq 100$ are associated with identified maternal role identity attainment but have a variation of heterogeneous research.

\section{Discussion}

This study confirmed an effect of maternal role intervention in pregnancy and postpartum can increasing the satisfaction of becoming a mother and decreasing depression. A previous study stated maternal role promotion activity elevated maternal role satisfaction 6 weeks after delivery month after labor [18]. Some studies have found that women with role satisfaction of becoming a mother have an increased MRA [4], [19]. The maternal role satisfaction increased with their positive feelings on their role competency. High satisfaction with proper nurture is predicted to contribute to the MRA [13], [14].

Stress was positively associated with anxiety. Financial anxiety is a known risk factor for postpartum stress. A previous study in China revealed that women in China feel worried of financial and work problems. Raising children is expensive to compare no children because parents will have spent much money than before. The financial problem is one of the main life stress sources in family in China and Hongkong [20], [21].

There is little consistent evidence that confinement practices decrease postpartum stress in Chinese. Specific components of confinement actions might decrease psychological distress in Chinese mothers of newborns, but these cannot be discerned from the existing evidence. The role of husbands in a mother's confinement process either as a provider of instrumental or emotional support, a buffer against mother-in-law tension, or a contributor to poor mental health through critical coercion or lack of support requires scrutiny [22].

Based on the results of the research discussion, one of the causes of infant and maternal health problems is the lack of readiness of prospective parents before marriage and before becoming parents and taking real roles as parents. Therefore, it is important to prepare for the transition period to become a mother. Empowering and making mothers to be ready to play their roles as a mother and have access of healthy reproductive organs as well as support infant growth and development.

\section{References}

1. Tansaz M, Nekolaltak M, Bios S. A comparative study of contraceptive methods in Iranian traditional medicine and modern medicine. J Med Hist. 2011;3:56-7.

2. Hosseini SM, Ghavami B, Salimzadeh H, Ardebili HE. Low birth weight and its association with unwanted pregnancies: A cohort study. J Public Health Inst Health Res. 2013;7:11-8.

3. Mercer RT. Becoming a Mother: Research on Maternal Role Identity from Rubin to the Present. New York: Springer; 1995.

4. Mercer RT. Becoming a mother versus maternal role attainment. J Nurs Scholarsh. 2004;36(3):226-32. PMid:15495491

5. Srisomboon A, Srisathien Y, Yusamran C. The effect of a maternal role promoting program on maternal role attainment in adolescent mothers with unplanned pregnancy. J Nurs Sci. 2011;29:74-81.

6. Ozkan H, Polat S. Maternal identity development education on maternity role attainment and my baby perception of primiparas. Asian Nurs Res (Korean Soc Nurs Sci) 2011;5(2):108-17. https://doi.org/10.1016/s1976-1317(11)60019-4. PMid:25030260

7. Sook BK. Effects of maternal role education program on the mother-infant interaction and infant development. Korean $\mathrm{J}$ 
Child Health Nurs. 2001;7:21-34.

8. Khakbazan Z, Jamshidbiki S, Gerenmayeh M, Tahmasebi S, Mehran A. The Effect of Education on Maternal Role Attainment and Stress in the Postpartum Period among Primiparous Women. [Degree of Master of Science in Midwifery]. Iran: Tehran University of Medical Sciences, Faculty of Nursing and Midwifery; 2014. https://doi.org/10.18869/acadpub. hnmj.27.2.17

9. Fouqueir KF. State of the science: Does the theory of maternal role attainment apply to African American motherhood? J Midwifery Womens Health. 2013;58(2):203-10. https://doi. org/10.1111/j.1542-2011.2012.00206.x

PMid:23437798

10. Liberati A, Altman DG, Tetzlaff J, Mulrow C, Gotzche PC, loannidis JP, et al. The PRISMA statement for reporting systematic reviews and meta-analyses of studies that evaluate healthcare interventions: Explanation and elaboration. BMJ. 2009;339:b2700. https://doi.org/10.1136/bmj.b2700

11. Cooke M, Schmied V, Sheehan A. An exploration of the relationship between postnatal distress and maternal role attainment, breast feeding problems and breast feeding cessation in Australia. Midwifery. 2007;23(1):66-76. https://doi. org/10.1016/j.midw.2005.12.003 PMid:17011682

12. Barlow A, Baker EV, Speakman K, Ginsburg G, Friberg I, Goklish N, et al. Home-visiting intervention to improve child care among American Indian adolescent mothers: A randomized trial. Arch Pediatr Adolesc Med. 2006;160(11):1101-7. https://doi. org/10.1001/archpedi.160.11.1101 PMid:17088511

13. Ngai FW, Chan SW, Ip WY. The effects of a childbirth psychoeducation program on learned resourcefulness, maternal role competence and perinatal depression: A quasiexperiment. Int J Nurs Stud. 2009;46(10):1298-306. https://doi. org/10.1016/j.jinurstu.2009.03.007 PMid:19361801

14. Hyun-Ju C, Sue K. Effects of maternal role practice education on becoming a mother. Korean J Women Health Nurs. 2011;17:5263. https://doi.org/10.4069/kjwhn.2011.17.1.52
15. Ngai FW, Chan SW. Stress, maternal role competence, and satisfaction among Chinese women in the perinatal period. Res Nurs Health. 2012;35(1):30-9. https://doi.org/10.1002/nur.20464 PMid:22024989

16. Kordi M, Fasanghari M, Asharipour N, Esmaily H. The effect of maternal role training program on role attainment and maternal role satisfaction in nulliparous women with unplanned pregnancy. J Educ Health Promot. 2017;6:61. PMid:28856163

17. Bagherinia M, Meedya S, Mirghafourvand M. Association between maternal sense of competence and self-efficacy in primiparous women during postpartum period. Shiraz E Med J. 2018;19(3):e59286. https://doi.org/10.5812/semj.59286

18. Phanthufak M, Phumonsakul S, Chareonpol O. The effect of a maternal role promoting program on maternal-infant attachment maternal role satisfaction, competency in infant behavior learning and infant growth. Rama Nurse J. 2009;15:149-61. https://doi.org/10.1016/0163-6383(94)90030-2

19. Hudson DB, Elek SM, Fleck CM. First-time mothers and fathers' transition to parenthood: Infant care selfefficacy, parenting satisfaction, and infant sex. Issues Compr Pediatr Nurs. 2001;24(1):31-43. https://doi. org/10.1080/014608601300035580 PMid: 11881635

20. Leung SSK, Arthur D, Martinson IM. Stress in women with postpartum depression: A phenomenological study. J Adv Nurs. 2005;51(4):353-60. https://doi. org/10.1111/j.1365-2648.2005.03506.x PMid:16086804

21. Nelson AM. Transition to motherhood. J Obstet Gynecol Neonatal Nurs. 2003;32(4):465-77. PMid:12903696

22. Wong J, Fisher J. The role of traditional confinement practices in determining postpartum depression in women in Chinese cultures: A systematic review of the English language evidence. J Affect Disor. 2009;116(3):161-9. https://doi.org/10.1016/j. jad.2008.11.002

PMid:19135261 